IZA DP No. 6003

Double-Sided Moral Hazard in Job Displacement Insurance Contracts

Donald O. Parsons

October 2011 


\title{
Double-Sided Moral Hazard in Job Displacement Insurance Contracts
}

\author{
Donald O. Parsons \\ George Washington University \\ and IZA
}

Discussion Paper No. 6003

October 2011

\author{
IZA \\ P.O. Box 7240 \\ 53072 Bonn \\ Germany \\ Phone: +49-228-3894-0 \\ Fax: +49-228-3894-180 \\ E-mail: iza@iza.org
}

Any opinions expressed here are those of the author(s) and not those of IZA. Research published in this series may include views on policy, but the institute itself takes no institutional policy positions.

The Institute for the Study of Labor (IZA) in Bonn is a local and virtual international research center and a place of communication between science, politics and business. IZA is an independent nonprofit organization supported by Deutsche Post Foundation. The center is associated with the University of Bonn and offers a stimulating research environment through its international network, workshops and conferences, data service, project support, research visits and doctoral program. IZA engages in (i) original and internationally competitive research in all fields of labor economics, (ii) development of policy concepts, and (iii) dissemination of research results and concepts to the interested public.

IZA Discussion Papers often represent preliminary work and are circulated to encourage discussion. Citation of such a paper should account for its provisional character. A revised version may be available directly from the author. 


\section{ABSTRACT \\ Double-Sided Moral Hazard in Job Displacement Insurance Contracts*}

Job displacement insurance typically includes both unemployment benefits and lump-sum severance pay, and each has provoked policy concerns. Unemployment insurance concerns have centered on distorted job search/offer acceptance decisions by the worker, severanceinduced firing cost concerns on excessive labor hoarding by firms. A single period private contracting model is used to investigate the interaction of these two seemingly distinct issues. Viewed singly, familiar results emerge. The absence of separation benefits of any kind leads to excessive labor hoarding as a primitive form of earnings insurance. In a limited information environment, the distribution of job displacement insurance between the two benefit types becomes important. Unemployment insurance benefits must be limited (relative to first-best levels) and severance pay made more generous. Firing cost considerations are less familiar. Because the firm wants to provide benefits, they cannot be "contracted around." Although formally driven by the sum of (unsubsidized) severance pay and expected unemployment benefits, the second-best firing cost program limits severance pay only. Together the two constraints create an unpromising contracting environment. The firing cost constraint is the more easily relaxed by government action - subsidies of sufficient size to one or another of the separation programs will work. Offer acceptance requires restrictions on leisure (workfare). Unfortunately, if first-best benefits are mandated, efficiency requires that both be eased.

JEL Classification: J65, J41, J33, J08

Keywords: job displacement, unemployment insurance, severance pay, moral hazard, firing costs

Corresponding author:

Donald O. Parsons

George Washington University

Economics Department

2115 G Street NW, Monroe Hall 368

Washington, DC 20052

USA

E-mail: dopars@gwu.edu

\footnotetext{
* The luxury of a sabbatical year at GW was important in later stages of this research. Earlier versions circulated under the title "Private Job Displacement Insurance: Information Asymmetries and Separation Pay Design." Comments on early drafts by Bryan Boulier, Timothy Perri, and Torben Tranæs are gratefully acknowledged, as are those of seminar participants at the Economic Policy Research Unit (EPRU) and the Center for Applied Microeconometrics (CAM), both at the University of Copenhagen; the Korea Labor Institute (Seoul, Korea); the World Bank/IIASA/Ludwig Boltzmann Institute International Workshop on Severance Pay Reform (Laxenberg/Vienna); the U.S. Bureau of Labor Statistics; George Washington University; and Ohio University.
} 


\section{Introduction}

Job displacement insurance packages typically include both unemployment benefits and fixed-sum severance pay, with both generating serious policy concerns. ${ }^{1}$ Unemployment insurance concerns have centered on distorted job search and offer acceptance decisions by the worker. ${ }^{2}$ The firing cost literature focuses on firm-held private information on demand that forces employers to self-finance displacement insurance, potentially inducing excessive labor hoarding. ${ }^{3}$ The interaction of these two potential distortions is complex and is the focus of this study.

The impact of worker-held private information on separation pay, with the risk of artificially extending unemployment duration spells, may be the more intensively studied. The absence of separation pay will induce excessive labor hoarding, Azariadis (1975) and Rosen (1985). Firms will increase the range of demand conditions under which they will retain the worker as a primitive form of earnings insurance. As insurance benefits increase, however, care must be taken in their form. The theoretical literature indicates that, if program administrators, private or public, are unable to monitor worker job search and/or offer acceptances, they should optimally restrict unemployment linked benefits and expand lump-sum severance pay. Baily (1977) for example made the now familiar argument that

"The larger the adverse incentive effect of UI on workers' job search, the larger should be the redundancy payments [severance pay] relative to the weekly benefit." Baily (1977, Proposition 4, p.504)

In a multi-period framework this notion generalizes to the proposition that UI benefits should decline with unemployment duration. ${ }^{4}$

1 For a sense of the two policy debates, see for example Atkinson and Micklewright (1991) and Blanchard (2006).

2 Important reviews of the optimal unemployment insurance literature include Holmlund (1998), Karni (1999), and Fredericksson and Holmlund (2006).

3 For a sample of the voluminous international "firing cost" literature, see Emerson (1988), Lazear (1990), Buechtemann (1992), Heckman and Pages (2004), and OECD (1999, 2004). For reviews see Blau and Kahn (1999) Addison and Teixeira (2003), and Boeri, Helppie, and Macis (2008) on employment protection effects, and Parsons (2011a) on severance plan effects.

4 Shavell and Weiss (1979) provides the standard early reference. See Pavoni (2007) for limits to this rule and more recent references. 
Concerns about severance-induced firing costs arose from policy concerns about severance pay mandates in many European economies, potentially linked to high levels of unemployment, Blanchard, Dornbusch, Dreze, Giersch, Layard, and Monti (1986), Emerson (1988) and Lazear (1990). The subsequent literature, theoretical and empirical, focused on the narrow question of the employment impact of government severance mandates, and not the implications for earnings insurance. ${ }^{5}$ Lazear's well-cited argument that firms can undo severance mandates with a simple bonding scheme does not apply here, because the firm finds it in its interest to supply earnings insurance (see however Section VI below). ${ }^{6}$

The double-sided moral hazard problem embedded in job displacement insurance contracts is the combination of worker moral hazard concerns (limited search and/or acceptance of formal jobs) and employer firing cost behaviors (excess labor hoarding). The double-sided nature of moral hazard in many employment contracting provisions has been noted. Early examples include studies of agricultural contracts in which both farmers (labor) and landowners provide unmonitorable resources, Reid (1977) and Eswaran and Kotwal (1985). Kahn and Huberman (1988) and Prendergast $(1993,1999)$ explored employment contract design if firm-specific human capital is valuable to the firm, but (i) the worker alone knows whether the training has occurred, and (ii) the firm alone measures the resulting productivity and assigns compensation. Galdon-Sanchez and Guell (2003) consider the difficulty of distinguishing dismissals for cause, which would involve no severance payout, from redundancy dismissals, which would. ${ }^{7}$

In this paper a simple theoretical insurance structure is developed that can encompasses these asymmetric information problems. $^{8}$ The private employment contract

5 The research into the dynamics of firing costs has also focused on the employment implications. Nickell (1978) and Bertola (1992) provide introductions to the underlying employment dynamics in a world of certainty. Bentolila and Bertola (1990) and Bertola (1990) introduce uncertainty.

6 See Blanchard (1998) for a discussion of the impact of the Lazear critique on subsequent work on mandated severance pay effects.

7 In this case, both employer and worker may know the facts, but have no incentive to report them truthfully if the third-party expected to adjudicate the dispute does not have that information.

8 Parsons (1986), Malcomson (1999), Prendergast (1999). and Salanié (2005) provide general reviews of the contracting literature. 
model is single period with demand uncertainty in the spirit of the implicit contract models of Azariadis (1975) and Rosen (1985). Because the "next job" is the primary form of consumption insurance for displaced workers, special attention is paid to the reemployment market, Baily (1977) and Gavin (1986). The single period model is used to address a rich set of insurance questions, but must ignore essentially multi-period issues such as individual or collective saving and borrowing strategies, Baily (1977), Sampson (1978), and Hopenhayn and Nicolini (1997). The model highlights the pervasive role of asymmetric information problems in job displacement design, and frames the deeper question of whether public intervention can "solve" any of these problems.

The paper proceeds as follows. A private contracting model of displacement with complete information provides a performance benchmark for more constrained information environments, Section II. The distinct roles of strategic labor hoarding, severance pay, and unemployment insurance emerge in an intuitive way. Asymmetric information problems are then introduced, beginning with worker-held information on job offer receipt, Section III. If layoffs remain optimal, UI benefits will be lower than first-best levels and severance benefits more generous, a result well-known in the social insurance literature. Firing cost concerns are then introduce in Section IV under the assumption that firms are unable to reinsure displacement losses in third party markets, presumably because they hold private information on their own business fortunes. Self-finance of job displacement benefits has predictable effects on severance pay and the risk of excessive labor hoarding in downturns.

The combination of the two constraints-search/unemployment benefits and layoff/firing costs-sharply limits the provision of job displacement insurance in many circumstances, Section V. Worker private information limits unemployment benefits and encourages severance payments, while firm private information discourages severance pay. The analysis turns in Section VI to a policy question--to what extent can public systems "solve" the asymmetric information problems that limit private provision? Firing cost issues are more easily handled--government subsidies for separation payments will do. If first-best 
benefit levels are mandated, simultaneous consideration of the two constraints is essential; if one is ignored, there is nothing gained from reforming the other. Section VII concludes.

\section{A Full Information Model of Private Job Displacement Insurance}

Under the assumption of full information, risk averse workers, and risk neutral firms, profit-maximizing firms will release workers if and only if it is efficient to do so, and will supply the ideal insurance package if it is. Consider a single period model with homogeneous workers and two types of firms/jobs, ones that require substantial advance planning, which will be called the contract market, and ones that do not, the spot market. At the beginning of the period, workers are free to choose jobs, contract or spot. Planning has its rewards and the worker's maximum productivity in the contract market is higher than in the spot market. However, employment in the contract market is not without risk; the contract market is subject to the possibility of a negative demand shock. The size of this shock is fixed to the firm (although it may vary across industries, larger in cyclical industries and smaller in stable ones). The contract employer can, of course, cushion the impact of contract loss on worker consumption, and will have an incentive to do so if administrative costs are small. The nature of the employment contract will be a function of these factors and also of the distribution of information across agents.

The Worker. The worker is assumed (i) to have an additively separable utility function in consumption and leisure, (ii) to be risk averse in consumption, and (iii) to face a dichotomous (zero-one) work choice. The worker's utility function is represented by:

$$
\begin{array}{ll}
U=u(C) & \text { if employed, } \\
U=u(C)+\ell, \ell>0 ; & \text { if unemployed, }
\end{array}
$$

where $u(C)$ is an increasing, concave function of consumption $C .^{9} \quad$ Assets and debts are zero by assumption, and consumption in this single period model therefore equal to income.

9 The specification implies that workers facing a costless, competitive insurance market will fully equalize consumption across states, which of course implies that the worker is better off in the layoff state because of the additional leisure. Note that this additively separable utility function is different from the utility function considered in Azariadis (1975) and Rosen (1985), which assumed that 
Worker risk is a function of the variability of productivity in the firm, the state of labor market demand external to the firm (reemployment probabilities and reemployment wage), and of course the contract the worker and firm negotiate to moderate contingencies.

The Contract Market. The value of a worker's product within the contracting firm is a random variable, which depends on the state of product demand. There are two mutually exclusive and exhaustive demand states, $S_{i}, i=1,2$, with a probability $\rho$ that $S_{1}$ will occur. ${ }^{10}$ Label $S_{1}$ and $S_{2}$ as the high-demand (good) state and low-demand (bad) state respectively. Productivities in the contract firm in the two states are:

$\begin{array}{lcl}\text { State } & \text { Probability } & \text { Productivity } \\ \mathrm{S}_{1}: & \rho & v, \quad v>0 \\ \mathrm{~S}_{2}: & (1-\rho) & \theta v, 0 \leq \theta<1 .\end{array}$

The Spot Market Firm. An independent spot market exists. Denote the spot market (and reemployment) job offer by $W^{R}$. Spot market jobs are available to a subset of displaced workers who must hastily explore the spot market after learning of a contract firm's layoff decision. Denote the probability of receiving a spot market job offer $W^{R}$ following displacement from a contract job by $\varphi, 0 \leq \varphi \leq 1$.

Assume that the worker's productivity in the spot market is greater than in the contract firm in the low demand state. Otherwise a guaranteed employment contract would dominate the layoff contract if the worker finds it optimal to work in both states. Therefore $\theta<\sigma<1$, where $\sigma$ denotes the spot market productivity parameter and the spot market job offer $W^{R}$ is assumed equal to productivity: $W^{R}=\sigma v$.

The contracting firm is risk neutral, with a utility function linear in expected profits $E(\pi)$, and finds it profitable to provide the risk averse worker with some form of earnings insurance. Two contract forms are considered below:

consumption and leisure are additively separable in a single argument of the utility function. For applications of the utility model used here, see Diamond and Mirrlees (1978) and Parsons (1996).

${ }_{10}$ Azariadis (1975) considers a set of productivity outcomes, Rosen (1985) a continuum, but these do not affect the basic structure of the insurance schemes and add substantially to the complexity of the model. The firm size issue embedded in these models is also ignored here. 


\section{GUARANTEED EMPLOYMENT (GE) \\ LAYOFF WITH SEPARATION BENEFITS (LAYOFF)}

The GE contract requires specification of wages in both high and low demand states $\left(W_{1}\right.$, $\left.W_{2}\right):$

\begin{tabular}{|l|c|c|c|}
\hline $\begin{array}{c}\text { GE } \\
\text { CONTRACT }\end{array}$ & & & \\
\hline \multicolumn{1}{|c|}{ STATE } & PROB. & PROD. & CONSUMPT \\
\hline $\mathrm{i}=$ & & & \\
\hline $\begin{array}{l}1 \text { (retained, } \\
\text { good state) }\end{array}$ & $\rho$ & $v$ & $W_{1}$ \\
\hline $\begin{array}{l}2 \text { (retained, } \\
\text { bad state) }\end{array}$ & $(1-\rho)$ & $\theta v$ & $W_{2}$ \\
\hline & & & \\
\hline
\end{tabular}

The LAYOFF contract requires specification of the wage in the high demand state $\left(W_{1}\right)$ and the separation package in the low. The separation package is characterized by the vector $(B, b)$, where $B$ denotes lump sum severance benefits and $b$ denotes unemploymentconditioned benefits.

In this single period model, the displaced contract worker either finds a job in the spot market or does not, and unemployment duration is either zero or one period. Contract workers will end up in one of three circumstances: (1) retained by the contracting firm, (2) laid off with no job offer, or (3) laid off with a job offer $W^{R}$. If all job offers are accepted, outcome probabilities, worker productivities, and consumption under LAYOFF contracts are:

\begin{tabular}{|l|c|c|c|}
\hline $\begin{array}{c}\text { LAYOFF } \\
\text { CONTRACT }\end{array}$ & PROB. & PROD. & CONSUMPT $_{\mathrm{i}}$ \\
\hline OUTCOME & CONG & & $W_{1}$ \\
\hline $\mathrm{j}=$ & $\rho$ (retained) & 0 & $B+b$ \\
\hline $\begin{array}{l}2 \text { (layoff, not } \\
\text { reemployed) }\end{array}$ & $(1-\rho)(1-\varphi)$ & $\sigma v=W^{R}$ & $B+W^{R}$ \\
\hline $\begin{array}{l}3 \text { (layoff, } \\
\text { reemployed) }\end{array}$ & $(1-\rho) \varphi$ & & \\
\hline
\end{tabular}

If the contracting firm retains workers in the low demand state as well as the high (the GE contract), the firm's expected profits $(\pi)$ are:

$$
E(\pi)=\rho\left[v-W_{1}\right]+(1-\rho)\left[\theta v-W_{2}\right]
$$


Conversely, if the firm retains workers only in the good state (LAYOFF), the firm's expected profits are:

$$
E(\pi)=\rho\left[v-W_{1}\right]-(1-\rho)[B+(1-\varphi) b],
$$

In the analysis to follow, optimal contract features will be characterized by maximization of worker expected utility for a given level of expected profits. ${ }^{11}$

Full Information Outcome. The full information insurance outcome is intuitive in these simple contracts. In both the GE and LAYOFF contracts, the worker and the firm negotiate an employment contract that offers the worker complete consumption insurance. If it is optimal to work in the contract firm in both states, GE is chosen and worker consumption in the two demand states will be equal. Under the zero (expected) profit constraint:

$$
C_{i}=W_{i}=\bar{I}, \quad \mathrm{i}=1,2 .
$$

where $\bar{I}=\rho v+(1-\rho) \theta v$, the worker's expected productivity if employed in both states.

The optimal LAYOFF contract will also smooth consumption perfectly across outcomes:

$$
C_{j}=\overline{\bar{I}}, j=1,2,3
$$

where $\overline{\bar{I}}=\rho v+(1-\rho) \varphi W^{R}$, the worker's expected productivity under the assumption that she works when jobs are offered.

The optimal LAYOFF contract in this environment takes the form:

$$
\begin{aligned}
& W_{1}^{*}=\overline{\bar{I}} . \\
& b^{*}=W^{R}, \\
& B^{*}=\overline{\bar{I}}-W^{R},
\end{aligned}
$$

where again $\overline{\bar{I}}=\rho v+(1-\rho) \varphi W^{R}$.

Note the distinct roles played by unemployment insurance and severance benefits. In this framework: unemployment insurance payments cover the loss of the reemployment wage by workers who cannot find reemployed, and severance benefits cover the

\footnotetext{
${ }^{11}$ Wages in the good state $\left(\mathrm{W}_{1}\right)$ will differ in the two contracts.
} 
reemployment wage losses common to all displaced workers, unemployed or reemployed. The severance benefit is essentially (scheduled) wage insurance.

Unemployment insurance benefits are linked only to the reemployment wage, but provisions of the full information LAYOFF contract vary with the reemployment likelihood and other parameters. For example, as the probability of reemployment increases, the worker is more likely to find another job and is wealthier; expected unemployment insurance expenditures decline, while wages in the high demand state and severance in the low demand state become more generous.

\section{Guaranteed Employment or Layoffs in the First Best Contract}

The efficient contract form, GE or LAYOFF, will of course depend on which is valued most highly by the worker. The worker will uniquely prefer the GE contract iff:

$$
\omega \equiv u\left(C^{*}\right)-u\left(C^{* *}\right)-(1-\rho)(1-\varphi) \ell>0,
$$

where

$$
\begin{array}{ll}
C^{*}=\rho v+(1-\rho) \theta v \equiv \bar{I}, & (\mathrm{GE}) \\
C^{* *}=\rho v+(1-\rho) \varphi W^{R} \equiv \overline{\bar{I}} . & (\text { LAYOFF })
\end{array}
$$

Equations (6) and (7) represent consumption in the first-best model in the GE and LAYOFF contracts respectively. Inspection of Equations (5)-(7) reveals that the GE contract will be preferred (i) the smaller the productivity contraction in the low demand state (the larger $\theta$ ), (ii) the lower the reemployment wage parameter $(\sigma)$, where $W^{R}=\sigma V$, and (iii) the less valued is leisure time $(\ell) .{ }^{12}$ Simple differentiation reveals that the probability of being reemployed if laid off $(\varphi)$ will decrease the attractiveness of the GE contract-assuming only that the worker would choose to work for the reemployment wage if offered.

Numerical Example. The models will become increasingly complex as informational limitations are introduced in the next several sections, and it will be useful to appeal to more explicit forms and a common numerical example to illustrate the impact of the informational

\footnotetext{
12 Note the parallels to Azariadis' discussion of the likelihood of layoff $(1975,1193-1194)$.
} 
limitation on contract provisions and the resulting consumption across outcomes. Consider the following model. A worker is characterized by a logarithmic consumption utility function:

$$
\begin{array}{lll}
U=\ln (C) & & \text { if employed; } \\
U=\ln (C)+\ell, \quad \ell>0, & & \text { if unemployed. }
\end{array}
$$

In the numerical example to follow, assume that leisure utility $(\ell)$ is 0.35 . Assume further that the contract workers is faced with a probability $\rho=0.85$ of realizing the good state, with good-state productivity normalized at one consumption unit $(v=1)$, and a probability of 0.15 of realizing the bad state. The productivity parameter in the contract firm $(\theta)$ is 0.5 if retained and the reemployment wage $\left(W^{R}\right)$ is 0.7 if laid off and reemployed. Summarizing:

$$
\begin{aligned}
& \ell=0.35 \\
& \rho=0.85 \\
& v=1.0 \\
& \theta=0.5 \\
& \sigma=0.7\left(W^{R}=\sigma v=0.7\right)
\end{aligned}
$$

Outcomes are easily derived in the first-best world. Consumption under the GE contract is not dependent on spot market conditions $\left(\varphi, W^{R}\right)$ and in this numerical example is 0.925. Consumption under the LAYOFF contract does depend on these parameters and layoffs become more attractive as the likelihood of securing the next job $(\varphi)$ increases. The consumption implications of the optimal contract type across all levels of reemployment probability $(\varphi)$ are illustrated in Figure 1A, the structure of contract type (GE or LAYOFF) and specific benefit provisions in Figure 1B. The GE contract is preferred to the FB LAYOFF model for: $\varphi<\varphi^{C}=0.475$. $^{13}$ At the critical threshold $\varphi=0.475$, consumption across outcomes is:

$$
\left(C_{1}, C_{2}, C_{3}\right)=(0.900,0.900,0.900)
$$

and the contract terms

$$
\left(W_{1}, \mathrm{~B}, \mathrm{~b}\right)=(0.900,0.200,0.7)
$$

\footnotetext{
${ }^{13}$ The critical phi $\left(\varphi^{C}\right)$ at which GE is no longer preferred declines to 0.420 if $W^{R}=0.75$, and 0.345 if $W^{R}=0.80$
} 
The introduction of information difficulties will limit the firm's ability to provide job displacement insurance, adversely affect layoffs or equivalently increase the range of GE contracts. In what follows we will use the intramarginal value:

$$
\varphi=0.55 \text {, }
$$

in order to insure that the layoff contract remains viable. With $\varphi=0.55$, consumption is:

$$
\left(C_{1}, C_{2}, C_{3}\right)=(0.908,0.908,0.908) \text {, }
$$

and the contract terms:

$$
\left(W_{1}, \mathrm{~B}, \mathrm{~b}\right)=(0.908,0.208,0.7),
$$

Table 1, Column 1.

The firing cost literature places great emphasis on the excessive retention of contract workers in the bad state, or labor hoarding. "Excess Labor Hoarding" is defined here as worker attachment to the contract firm in excess of that in the first-best contract. The extent of labor hoarding will be indexed by the range of reemployment probabilities over which GE contracts dominate LAYOFF contracts. Excess labor hoarding in the full information case is zero by definition.

\section{Private (Worker) Information on Reemployment Job Offers}

Turning to potential asymmetric information problems, consider first privately held information by the worker. Employers are likely to find information on separated workers, especially on job search and information acceptance, costly to collect. Consider the situation in which:

Asymmetry Assumption 1: The firm can observe post-separation employment activity, but not job offer arrivals.

Asymmetry Assumption 1 is familiar from the public unemployment insurance literature, in which the government is presumed to be able to monitor actual work activity, but not job offers, which workers may strategically ignore. ${ }^{14}$

Under the first best LAYOFF contract, the worker has no incentive to reveal employment offers; income is the same and leisure less with a return to work. If the employer is to induce the worker to reveal truthfully the arrival of wage offers, the separation

14 Search effort, not modeled here, is of course also vulnerable to moral hazard. 
pay package must insure that the displaced worker is motivated to accept any wage offers she receives. This requires an Offer Revelation Constraint (ORC):

$$
\left[u\left(C_{2}\right)+\ell\right]-u\left(C_{3}\right) \leq 0
$$

where $C_{2}=B+b$ and $C_{3}=B+W^{R}$.

The relevant Lagrangian for the second-best ORC LAYOFF contract is conveniently optimized in consumption form:

$$
\begin{aligned}
\Lambda=\rho u & \left(C_{1}\right)+(1-\rho)(1-\varphi)\left\{u\left(C_{2}\right)+\ell\right\}+(1-\rho) \varphi u\left(C_{3}\right) \\
& -\lambda\left\{\rho C_{1}+(1-\rho)(1-\varphi) C_{2}+(1-\rho) \varphi C_{3}-\rho v-(1-\rho) \varphi W^{R}\right\} \\
& -\mu\left[\left\{u\left(C_{2}\right)+\ell\right\}-u\left(C_{3}\right)\right] .
\end{aligned}
$$

which is to be optimized with respect to $C_{1}, C_{2}, C_{3}, \lambda$, and $\mu(\mu \geq 0)$. The resulting first order conditions for an interior solution are:

$$
\begin{aligned}
& u^{\prime}\left(C_{1}\right)-\lambda=0 \\
& (1-\rho)(1-\varphi)\left[u^{\prime}\left(C_{2}\right)-\lambda\right]-\mu u^{\prime}\left(C_{2}\right)=0 \\
& (1-\rho) \varphi\left[u^{\prime}\left(C_{3}\right)-\lambda\right]+\mu u^{\prime}\left(C_{3}\right)=0 \\
& -\left[\rho C_{1}+(1-\rho)(1-\varphi) C_{2}+(1-\rho) \varphi C_{3}-\rho v-(1-\rho) \varphi W^{R}\right]=0 \\
& \quad-\left[\left\{u\left(C_{2}\right)+\ell\right\}-u\left(C_{3}\right)\right] \geq 0 . \\
& \mu \geq 0, \mu \cdot\left[\left\{u\left(C_{2}\right)+\ell\right\}-u\left(C_{3}\right)\right]=0 .
\end{aligned}
$$

It is trivial to prove that the work constraint is binding if it is rational to have the displaced worker accept a job offer, so that $(10 \mathrm{e})$ can be treated as an equality constraint. The ideal is equal consumption across states, and the limitation on unemployment benefits should be as small as feasible.

Combining 10a-10c yields an important redistributive principle common in this class of problems, ${ }^{15}$

$$
\frac{1}{u^{\prime}\left(C_{1}\right)}=(1-\varphi) \frac{1}{u^{\prime}\left(C_{2}\right)}+\varphi \frac{1}{u^{\prime}\left(C_{3}\right)}
$$

\footnotetext{
${ }^{15}$ See for example Parsons (1996) and Viard (2001).
} 
The inverse of the marginal utility of consumption in the no-layoff state equals the weighted average of the inverses of the marginal utilities in the two layoff states, with the weights the probability of receiving a job offer if laid off. The redistributive principle leads to the important proposition that:

Proposition 1: Under ORC, if it is optimal to accept a reemployment job offer, the ORC LAYOFF contract will be characterized by

$$
C_{2} \leq C_{1} \leq C_{3} \text {, with } C_{2}=C_{1} \text { iff } \varphi=0 \text { and } C_{3}=C_{1} \text { iff } \varphi=1 .^{16}
$$

The work/no-work consumption differential is met by an increase in consumption if laid off and reemployed $\left(C_{3}\right)$ and a decrease in consumption if laid off and unemployment $\left(C_{2}\right)$ relative to the no-layoff (good) state $\left(C_{1}\right)$.

The contract terms can then be solved recursively as:

$$
\begin{aligned}
& W_{1}=C_{1} \\
& B=C_{3}-W^{R} \\
& b=C_{2}-B
\end{aligned}
$$

The firm, like public authorities, must limit the generosity of unemployment benefits if it is to induce the worker to reveal the existence of a wage offer.

The optimizing values are easily solved in explicit form for the logarithmic utility function. Consumption across outcomes takes the form:

$$
\begin{aligned}
& C_{1}=\overline{\bar{I}}, \\
& C_{2}=\frac{\overline{\bar{I}}}{\varphi e^{\ell}+(1-\varphi)}, \text { and } \\
& C_{3}=\frac{e^{\ell \bar{I}}}{\varphi e^{\ell}+(1-\varphi)}
\end{aligned}
$$

where $\overline{\bar{I}}=\rho v+(1-\rho) \varphi W^{R}$, the worker's expected total earnings if he accepts reemployment wage offers if laid off.

In the log utility function, the expected result holds; the explicit wage and benefit contract functions imply:

$$
W=\overline{\bar{I}}
$$

${ }^{16}$ The ORC layoff contract will of course not be observed below a critical $\varphi$ level: the GE contract will be preferred. 


$$
\begin{aligned}
& b=W^{R}-\frac{\left(e^{\ell}-1\right) \overline{\bar{I}}}{\varphi e^{\ell}+(1-\varphi)}<b^{*}, \text { and } \\
& B=\frac{e^{\ell} \overline{\bar{I}}}{\varphi e^{\ell}+(1-\varphi)}-W^{R}>B^{*}
\end{aligned}
$$

where asterisks denote the first-best values. Equation (13b) indicates that unemployment benefits in the ORC LAYOFF are less than in the FB LAYOFF contract, and (13c) that severance pay is greater. Summarizing:

Proposition 2: Under ORC and a logarithmic utility function--if it is optimal to accept a reemployment job offer, UI benefits are lower and severance pay is higher than in the first-best model.

Numerical example. Consider the numerical example of the last section. The offer revelation constraint, Equation (8) above, weighs heavily on unemployment benefits. The second-best LAYOFF contract is

$$
\left(W_{1}, B, b\right)=(0.908,0.347,0.391)
$$

Table 1, Column 3. Relative to the first-best layoff contract, unemployment benefits are 44 percent lower while severance pay is 88 percent higher. The consumption differential across outcomes, and especially across displaced workers under ORC, is substantial:

$$
\left(C_{1}, C_{2}, C_{3}\right)=(0.908,0.738,1.047) \text {. }
$$

The critical threshold at which ORC LAYOFF is superior to the GE contract rises to $\varphi^{C}=0.515$ (implying excess labor hoarding of eight percent), reflecting the imperfections of the second-best contract.

As the probability of finding another job $(\varphi)$ increases, layoffs become more attractive. Above the critical $\varphi$ threshold, consumption (Figure 2A) and the underlying contract parameters (Figure 2B) vary systematically across reemployment probabilities in plausible ways. When reemployment is less likely, the optimal ORC LAYOFF contract relies heavily on severance pay. As the likelihood of finding another job $(\varphi)$ increases, lump-sum benefits become less important in the second-best ORC package and UI benefits more generous. 


\section{Private (Employer) Information and the Firing Cost Constraint}

Employers also hold private information that is not in their interests to divulge under the terms of the first-best contract, for example information on demand conditions. This private information limits the employer's ability to reinsure with third parties, and simultaneously limits its ability to promise its workers generous (self-financed) separation benefits. Unlike temporary separation risk, which can be monitored cheaply through experience rating of claims behavior, permanent separations are often precipitated by large demand shocks and by plant closings perhaps unique in the firm's experience. Stock markets appear to be surprised by firm plant-closing announcements, and one could expect that workers and insurers are as well. ${ }^{17}$ Formally denote this information restriction as:

Asymmetry Assumption 2: Only the firm observes its own product demand state.

In this case the firm must self-finance the separation package, which has potentially important contract implications. The reporting of demand state is irrelevant under GE, the conditions of which do not vary with demand. Under LAYOFF, however, the firm may have an incentive to misreport the low demand state as high, inducing the worker to work in the low demand state. ${ }^{18}$ This is the firing cost problem noted in the mandated severance pay literature, although, with fully rational voluntary exchange, the worker will recognize the moral hazard problem embedded in LAYOFF and demand either GE or a restructured LAYOFF.

To insure truthful reporting of the low demand state by the risk neutral firm following layoff, the net cost of retaining a worker in that state $\left[W_{1}-\theta v\right]$ must equal or exceed expected payouts to laid-off workers $[B+(1-\varphi) b]$ :

\footnotetext{
${ }^{17}$ For empirical evidence of stock price effects of plant closing announcements, see Blackwell, Marr, and Spivey (1990), Gombola and Tsetsekos (1992), and Clinebell and Clinebell (1994). Hallock (2010, p.85, Table 2) reports that the impact of layoff announcements on stock prices varies with economic conditions, and was substantial during the 1970s and 2000s, modest in the 1980s, and nonexistent in the 1990s. Plant closings as opposed to layoffs for other reasons appeared to have no additional stock market effect.

${ }_{18}$ This is a problem of course only because the total compensation package in this contract assumes that the worker will be given leisure in the low demand state and provides a lower wage when working as a consequence.
} 


$$
W_{1}-\theta v-[B+(1-\varphi) b] \geq 0
$$

or in consumption terms:

$$
C_{1}-(1-\varphi) C_{2}-\varphi C_{3}-\theta v+\varphi W^{R} \geq 0 .
$$

Denote this as the Firing Cost Constraint (FCC).

At the first-best values, the employer has no incentive to respond truthfully if:

$$
\varphi W^{R}-\theta v<0
$$

In the absence of reemployment possibilities $(\varphi=0)$, the employer will never report realization of the bad state truthfully under the first-best contract. If reemployment prospects are high, the expected cost of the separation package is smaller and first-best policy parameters may not induce misreporting. Note that the likelihood of misreporting varies with parameters in the same direction as GE contracts vary-positive if retention is costly (the alternative use of time valuable and negative if retention is unproductive). Only leisure value is irrelevant to the firing cost measure while of negative value in the GE calculation.

The optimal contract emerges from maximization of the worker's expected utility subject to (i) the firm's zero profit constraint:

$$
\rho W_{1}+(1-\rho)[B+(1-\varphi) b]-\rho v=0
$$

or in consumption terms:

$$
\rho C_{1}+(1-\rho)(1-\varphi) C_{2}+(1-\rho) \varphi C_{3}-\rho v-(1-\rho) \varphi W^{R}=0,
$$

and (ii) the firing cost constraint (Equation 14b) if binding. The corresponding Lagrangian $(\Lambda)$ is:

$$
\begin{aligned}
\Lambda=\rho u & \left(C_{1}\right)+(1-\rho)\left[(1-\varphi)\left\{u\left(C_{2}\right)+\ell\right\}+\varphi u\left(C_{3}\right)\right] \\
& -\lambda\left[\rho C_{1}+(1-\rho)(1-\varphi) C_{2}+(1-\rho) \varphi C_{3}-\rho v-(1-\rho) \varphi W^{R}\right] \\
& -\mu\left[C_{1}-(1-\varphi) C_{2}-\varphi C_{3}-\theta v+\varphi W^{R}\right]
\end{aligned}
$$

The Lagrangian $\Lambda$ is to be optimized with respect to $C_{1}, C_{2}, C_{3}, \lambda$, and $\mu, \mu \geq 0$

The resulting first order conditions are:

$$
\begin{aligned}
& \rho\left[u^{\prime}\left(C_{1}\right)-\lambda\right]-\mu=0 ; \\
& (1-\rho)\left[u^{\prime}\left(C_{2}\right)-\lambda\right]+\mu=0,
\end{aligned}
$$




$$
\begin{gathered}
(1-\rho)\left[u^{\prime}\left(C_{3}\right)-\lambda\right]+\mu=0 \\
-\left[\rho C_{1}+(1-\rho)(1-\varphi) C_{2}+(1-\rho) \varphi C_{3}-\rho v-(1-\rho) \varphi W^{R}\right]=0 \\
\quad-\left[C_{1}-(1-\varphi) C_{2}-\varphi C_{3}-\rho v+\varphi W^{R}\right] \geq 0 \\
\mu \geq 0 \quad \mu \cdot\left[C_{1}-(1-\varphi) C_{2}-\varphi C_{3}-\rho v+\varphi W^{R}\right]=0
\end{gathered}
$$

The firing cost constraint will be effective and Expression (17e) becomes an equality as long as $\varphi W^{R}-\theta v<0$. Note that $17 \mathrm{~b}$ and $17 \mathrm{c}$ together yield:

$$
u^{\prime}\left(C_{2}\right)=u^{\prime}\left(C_{3}\right)
$$

which implies

$$
C_{2}=C_{3} \text { and therefore that } b=W^{R},
$$

the first-best unemployment insurance benefit. The constraint limits only severance benefits in the second-best contract (note that Equations 17a-c insure that consumption in the high demand state exceeds consumption in the low demand state as long as FCC is effective. In short, an effective FCC induces a wedge between consumption in the high demand state and in the low demand state, but not across outcomes in the low demand state:

$$
C_{1} \geq C_{2}=C_{3} \text {. }
$$

Solving the system yields the following consumption plan:

$$
\begin{aligned}
& C_{1}=\rho v+(1-\rho) \theta v \equiv \bar{I} \\
& C_{2}=C_{3}=\rho(1-\theta) v+\varphi W^{R} .
\end{aligned}
$$

\section{Summarizing:}

Proposition 3: The FCC LAYOFF contract is characterized by (i) equality of consumption among low demand outcomes (unemployment or reemployment), and (ii) consumption inequality between the high demand outcome and the two low demand outcomes, with consumption higher in the high demand outcome.

If an otherwise complete separation contract is constrained by the firing cost constraint, contract provisions take the form:

$$
\begin{aligned}
& W_{1}=\bar{I}, \\
& B=\rho(1-\theta) v-(1-\varphi) W^{R}, \text { and } \\
& b=W^{R}
\end{aligned}
$$

where $\bar{I}=\rho v+(1-\rho) \theta v$.

Proposition 4: The firing cost constraint weighs entirely on severance pay. 
Basically the second-best employment contract smoothes consumption across outcomes in the low demand state by paying full unemployment benefits and meets the FCC constraint by limiting severance pay.

The FCC LAYOFF contract limits severance payments more severely the milder the productivity decline in the bad state (the larger $\rho$ ). ${ }^{19}$ Of course the milder the productivity decline, the more likely it is that the worker prefers a GE contract as a first-best contract. FCC reduces the expected utility value of the LAYOFF contract, but is irrelevant for the GE contract, revealing that the range of conditions over which GE is preferred is larger than in the first-best. Excessive labor hoarding is more likely. "Firing cost" distortions arise in private, voluntary separation plans; excess labor hoarding (the GE contract) may be induced by employer-financed separation costs. ${ }^{20}$

Numerical example. In the numerical example, the FCC LAYOFF contract is now:

$$
\left(W_{1}, B, b\right)=(0.925,0.11,0.7)
$$

Table 1, Column 4. Severance benefits are slightly more than half the first-best level of 0.208. The consumption differentials across outcomes under FCC are:

$$
\left(C_{1}, C_{2}, C_{3}\right)=(0.925,0.81,0.81)
$$

GE is superior to the FCC LAYOFF contract for $\varphi \leq 0.505$, implying a 6 percent increase in the GE range because of this layoff contract inefficiency. ${ }^{21}$

Because expected firing costs are the sum of severance pay and expected unemployment insurance benefits, they decrease as the probability of reemployment increases. In the numerical example, the FCC constraint ultimately becomes ineffective for $\varphi>0.714$. The impact of FCC on consumption by outcome across reemployment probability is illustrated in Figure 3A, and corresponding contract provisions in Figure 3B.

\footnotetext{
19 Recall that $\theta$, the low demand productivity parameter, does not affect the LAYOFF contract, only the likelihood that it dominates or is dominated by the GE contract.

20 The firm has no incentive to contract around the voluntarily supplied severance benefit as it does with government-mandated benefits in excess of those voluntarily supplied, Lazear (1990). See also Parsons $(2011 \mathrm{~b}, \mathrm{c})$.

${ }^{21}$ Recall that the critical $\varphi$ in the first best case is 0.475 .
} 


\section{Double-Sided Moral Hazard: FCC and ORC}

In this section I focus on a combination of hidden information problems--worker hidden information on job offers and employer hidden information on labor demand. Given the well-known property of the offer revelation constraint to limit UI benefits and expand severance benefits to increase the displaced worker's earnings stability, the question may be usefully framed as the impact of the firing cost constraint on the ORC second best contract.

Consider the joint impact of the two. If both FCC and ORC are effective, the firm faces three constraints in setting contract terms-the two potential incentive compatibility constraints, ORC (Equation 8) and FCC (Equation 14a)-and the zero profit constraint (ZPC):

$$
\begin{array}{ll}
u(B+b)=u\left(B+W^{R}\right)-\ell & \text { ORC } \\
B+(1-\varphi) b=W_{1}-\theta v & \text { FCC } \\
\rho W_{1}+(1-\rho) B+(1-\rho)(1-\varphi) b=\rho v & \text { ZPC }
\end{array}
$$

Equivalently posed in consumption terms:

$$
\begin{aligned}
& u\left(C_{2}\right)=u\left(C_{3}\right)-\ell . \\
& C_{1}-(1-\varphi) C_{2}-\varphi C_{3}=\theta v-\varphi W^{R} \\
& \rho C_{1}+(1-\rho)(1-\varphi) C_{2}+(1-\rho) \varphi C_{3}=\rho v+(1-\rho) \varphi W^{R}
\end{aligned}
$$

we can solve directly for $\left(C_{1}, C_{2}, C_{3}\right)$.

Denote layoff contracts that must satisfy both the worker-hidden information constraint (ORC) and the firing cost constraint (FCC) as ORC\&FCC LAYOFF contracts. The two incentive compatibility constraints, when combined with the zero profit constraint, fully determine the three layoff contract parameters $\left(W_{1}, B, b\right)$ or equivalently $\left(C_{1}, C_{2}, C_{3}\right)$. Worker preferences enter the solution only through the incentive compatibiity constraints.

The optimal contract shifts insurance payouts from unemployment insurance to severance pay in order to induce revelation of reemployment offers (ORC). The form and overall magnitudes of the offsets are limited however by FCC, which induces a reduction in severance pay. If the worker is to reveal job offers and the firm the demand state, the 
consumption differential between separated workers who find work and those who do not must be maintained, but the separation package must be less generous in total.

Consider the logarithmic case. If both the ORC and FCC constraints are effective, the three constraints together yield closed form solutions for consumption:

$$
\begin{aligned}
& C_{1}=\bar{I} \\
& C_{2}=\frac{\tilde{I}}{\varphi e^{\ell}+(1-\varphi)} \\
& C_{3}=\frac{e^{\ell \tilde{I}}}{\varphi e^{\ell}+(1-\varphi)}
\end{aligned}
$$

where $\bar{I}=\rho v+(1-\rho) \theta v$ and $\tilde{I}=\rho(1-\theta) v+\varphi W^{R}{ }^{22} \quad$ The corresponding contract parameters are:

$$
\begin{aligned}
& W=\bar{I} \\
& B=\frac{e^{\ell} \tilde{I}}{\varphi e^{\ell}+(1-\varphi)}-W^{R} \\
& b=W^{R}-\frac{\left(e^{\ell}-1\right) \tilde{I}}{\varphi e^{\ell}+(1-\varphi)} .
\end{aligned}
$$

A casual comparison of consumption under the ORC\&FCC contract, (22a)-(22c) and consumption under ORC contracts, (12a-12c), and FCC contracts, (18a-18b), makes clear the simplicity of the jointly constrained contract. ORC requires a negative wedge between unemployment consumption $\left(\mathrm{C}_{2}\right)$ and reemployment consumption, $\left(\mathrm{C}_{3}\right)$, and $\mathrm{FCC}$ requires a limit on expected separation benefits relative to wages in the good state. If FCC is effective, the $\mathrm{C} 2 / \mathrm{C} 3$ ratio $\left(\mathrm{e}^{-\ell}\right)$ is maintained, but expected benefit layouts are smaller:

$$
\rho(1-\theta) v+\varphi W^{R}-\left[\rho v+(1-\rho) \varphi W^{R}\right]=\rho\left[\varphi W^{R}-\theta v\right]<0 .
$$

Consider:

Proposition 5: Under a logarithmic utility function, the imposition of an effective FCC on an effective ORC will lead (i) to a reduction in consumption of both unemployed and reemployed layoffs $\left(\mathrm{C}_{2}\right.$ and $\left.\mathrm{C}_{3}\right)$, and (ii) a reduction in severance benefits and an increase in unemployment benefits.

This proposition follows immediately from subtraction of the consumption and contract parameter measures under joint ORCFCC (Equation sets 22a-c and 23a-c respectively) and

\footnotetext{
22 Note the different income measures in (22a) and in (22b) and (22c).
} 
under ORC alone (Equation sets 12a-c and 13a-c respectively) and the effective FCC condition (Inequality 14a): ${ }^{23}$

$$
\varphi W^{R}-\theta v<0 .
$$

Numerical example. The limited benefits in the second-best contracts increase the range of conditions over which GE contracts dominate, reducing (somewhat) the flexibility of the labor market—-that is the likelihood that the firm will lay off the worker in the low demand state. The impact on excessive labor hoarding is modest by design; insurance payouts of both kinds are restricted in order to limit layoff distortions. ${ }^{24}$ In the numerical model, the critical threshold below which GE contracts will be preferred $\left(\varphi^{C}=0.475\right.$ in the first best world) increases to 0.505 with employer-hidden information, to 0.515 with worker-hidden information, and to 0.53 with both information problems simultaneously.

The consumption profile when all constraints are effective is:

$$
\left(C_{1}, C_{2}, C_{3}\right)=(0.925,0.659,0.934) \text {. }
$$

and the contract provisions:

$$
\left(W_{1}, B, b\right)=(0.925,0.234,0.424) \text {. }
$$

Table 1, Column 5. Consumption of the unemployed is 29 percent less than among those retained.

The impacts of the various constraints, individually and in combination, are illustrated for the usual example values in Figure 4. Singly, ORC depresses unemployment benefits and expands severance benefits. FCC depresses severance benefits only. ${ }^{25}$ An effective ORC primarily limits the generosity of unemployment benefits (b), encouraging severance pay, while an effective FCC limits severance pay. The effects are substantial. If worker private information is the sole issue, UI benefits are 44 percent lower and severance benefits

\footnotetext{
23 Note that (14') reduces to (14a) under ORC values as well as first-best values.

24 Alternatively contracts (GE contracts) are written that recognize the reality that layoffs will not occur in the low demand state.

25 Note that the offer revelation constraint involves the simple sum of unemployment and severance benefits, the firing cost constraint the sum of severance and expected unemployment benefits. As long as the probability of reemployment is less than one, the firing cost constraint will favor unemployment benefits in any reduction.
} 
88 percent higher than the first-best levels, with the net effect on consumption of the unemployed a substantial drop of about 19 percent from first-best levels. The addition of FCC induces a shift away from severance benefits of 33 percent, though with a slight increase in unemployment benefits of 8.4 percent. The net result of the additional constraint is a drop of 11 percent in the consumption of the unemployed (form ORC levels).

Over the full range of reemployment probabilities $(\varphi)$, a more complete set of strategies emerges. In the numerical example, the firing cost constraint is ineffective if the probability of reemployment of laid off workers is sufficiently large, because first-best expected separation benefits are less costly, and the second-best outcome reverts to the ORC outcome. The GE contract dominates until $\varphi=0.535$, after which the dual incentive compatibility constraints apply until $\varphi=0.714$. At that point, the FCC constraint is no longer effective, and only the ORC constraint applies. The structure of consumption by outcome across reemployment probabilities and the corresponding structure of contracts are illustrated in Figure 5A and 5B respectively for the numerical example employed throughout the paper.

\section{Asymmetric Information and the Limits of Government}

The question remains whether government interventions of some sort would ease these insurance limits and the excess labor hoarding they imply. Mandating first-best severance pay and unemployment benefits is not a solution, but will simply induce large increases in labor hoarding. ${ }^{26}$ Put otherwise, the GE contract would be adopted throughout the range of reemployment probabilities. Both parties to the contract rationally act "as if" the reemployment probability is zero, even though it would not be in a full information economy, or a second-best contract for that matter. Job separation benefits may be generous in a

${ }^{26}$ Government mandating of first-best severance payments in excess of what the firm would choose to offer is subject to the Lazear (1990) critique, that firms can simply undo the mandated excess (as the firm views it) with a simple bonding scheme. In a multiperiod model, severance savings plans would be a more familiar mechanism, Parsons $(2011 b, c)$. These concerns are also easy for governments to deal with. 
mandated first-best benefit scheme with second-best information, but would never be paid in this model.

Subsidies are perhaps more promising and indeed are common. Unemployment insurance taxes are only partially linked to a firm's benefit payouts in the United States (incomplete experience rating) and not at all in most European countries. Severance benefits, whether mandated (as in much of Europe) or voluntary (as in the U.S.), are unsubsidized. Subsidies are typically accompanied by benefit mandates, which provide a limit on strategic exploitation of subsidies by the firm.

One can easily design a subsidy that would eliminate FCC as an effective constraint. If unemployment benefits and severance benefits are mandated at first-best levels, a subsidy of a given amount to either expected unemployment benefits or severance benefits or some combination of the two would eliminate the firing cost constraint. In the numerical example, the firm would lay off workers in first-best circumstances with mandated first-best benefits as long as the government absorbed 29.5 percent of total expected separation costs. $^{27}$

Inducing workers to reveal job offers is not so easily done, assuming one wants to secure the first-best compensation scheme. Cost subsidies (for given benefits) are not relevant to the worker's decision. The worker cares about what she receives--that is benefits and of course leisure. To make reemployment attractive:

$$
u\left(C_{2}\right) \leq u\left(C_{3}\right)-\ell
$$

or in logarithmic form

$$
C_{2} \leq e^{-\ell} C_{3}
$$

where $0 \leq e^{-\ell}<1$. No monetary subsidy will induce first-best consumption outcomesequality of income across all states. A subsidy to reemployment earnings, for example, would fatten the reward to unemployed workers for accepting job offers while maintaining

27 This calculation assumes that the subsidy is financed by a lump sum payroll tax of 2.5 percent of the value of production in the high demand state $(0.025 \mathrm{v})$. 
separation payments at their first-best levels, but would leave the reemployed better off. Complete consumption insurance is feasible with a tax or levy on leisure time, indexed by $\ell$, but, like any "ordeal." is unlikely to be utility maximizing. Still consumption would converge across outcomes for the displaced as the leisure of the unemployed is diminished, and may form the intuitive basis for active labor market policies or workfare. ${ }^{28}$

\section{Conclusion}

From the private employer's perspective, workers can be insured against job displacement losses either by labor hoarding during difficult times (guaranteed employment) or by providing a separation benefit package. In the ideal package, firms would retain workers (hoard labor) if demand shocks are small and smooth consumption across outcomes if layoffs are called for. Unemployment insurance would smooth income between reemployed workers and the unemployed, and severance pay would offset losses common to all separated workers, essentially offering scheduled wage insurance benefits.

A variety of asymmetric information problems limits the private provision of job displacement insurance, forcing firms either (i) to expand their labor hoarding activities or (iia) to limit job displacement benefits in order to induce workers on layoff to accept reemployment offers and (iib) severance payments to assure workers that layoffs will be made in appropriate circumstances. The insurance motivation insures that firing cost limitations fall solely on severance, not unemployment insurance benefits. When both constraints are effective, a second-best contract emerges that severely limits job displacement benefits of both kinds, and modestly expands the range of excessive labor hoarding. Unemployment benefits must be limited in order to encourage the unemployed worker to accept a reasonable job offer, but the usual insurance offset-higher severance payments-is blocked by the firing cost constraint. Both severance benefits and the expected value of unemployment insurance, disproportionately severance benefits, are

${ }^{28}$ Besley and Coate (1992) provide a general introduction, Kreiner and Tranæs (2005) a specific workfare model. 
forced down so that the firm is not discouraged from laying off the worker in the low demand state. $^{29}$

Public mandating of generous $\mathrm{UI}$ and severance benefits does not solve the joint problems, and indeed induces extreme levels of excessive labor hoarding, which appears in the present model as reliance on guaranteed employment contracts. An interesting question is whether the government can provide offsets that would allow the firms to provide first-best benefits when appropriate. The two constraints are not equally easy to relax. The firing cost constraint is relatively easily eased by subsidizing separation benefits of either type, which is commonly done for unemployment benefits (though not necessarily for that reason). Such subsidies, however, have no impact on the offer revelation constraint, which depends entirely on the worker's receipt of benefits, not the cost of those benefits to the employer. Only levies on the unemployed worker's leisure would appear to ease the second constraint if insurance motivates government activity. If governments mandate first-best severance and unemployment insurance, easing one of the constraints and not the other will not lead to first-best outcomes; piece-meal reforms appear of little value.

29 The model also reveals that the firm has no incentive to undo its severance pay offering, unless benefits in excess of second-best levels are mandated. 


\section{REFERENCES}

Addison, John, and Paulino Teixeira. 2003. "The Economics of Employment Protection," Journal of Labor Research, Vol. 24.1 (Winter): 85-129.

Atkinson, Anthony B. and Micklewright, John. 1991. "Unemployment Compensation and Labor Market Transitions: A Critical Review." Journal of Economic Literature 29 (December): 1679-1727.

Azariadis, Costas. 1975. "Implicit Contracts and Underemployment Equilibria," Journal of Political Economy, 83 (December): 1183-1202.

Baily, Martin Neil. 1977. “Unemployment Insurance.as Insurance for Workers” Industrial and Labor Relations Review 30 (July): 495-504.

Bentolila, Samuel and Giuseppe Bertola. 1990. "Firing Costs and Labor Demand: How Bad is Eurosclerosis?" Review of Economic Studies 57.3(July): 381-402.

Bertola, Giuseppe. 1990. "Job Security, Employment, and Wages." European Economic Review 34 (1990): 851-886.

Bertola, Giuseppe. 1992. "Labor Turnover Costs and Average Labor Demand." Journal of Labor Economics" 10(October): 389-411.

Besley, Timothy and Stephen Coate, "Workfare versus Welfare: Incentives Arguments for Work Requirements in Poverty-Alleviation Programs," American Economic Review 82 (1992): 249-261.

Blackwell, David W.; M. Wayne Marr, and Michael F. Spivey. 1990. "Plant-Closing Decisions and the Market Value of the Firm Source," Journal of Financial Economics v26.2 (August): 277-88.

Blanchard, Olivier. 1998. "Employment Protection and Unemployment." mimeo.

Blanchard, Olivier. 2006. "European Unemployment: The Evolution of Facts and Ideas," Economic Policy (January): 5-59.

Blanchard, Olivier, Rudiger Dornbusch, Jacques Dreze, Herbert Giersch, Richard Layard, and Mario Monti. 1986. "Employment and Growth in Europe: A Two-Handed Approach, in Blanchard, Olivier, Rudiger Dornbusch, and Richard Layard, eds., Restoring Europe's Prosperity: Macroeconomic papers from the Centre for European Policy Studies, MIT Press: Cambridge, MA 1986: 95-124.

Blau, Francine, and Lawrence M. Kahn. 1999. "Institutions and Laws in the Labor Market," in Orley Ashenfelter and David Card, eds. Handbook of Labor Economics, Vol. 3 13991461.

Boeri, Tito, Brooke Helppie, and Mario Macis. 2008. "Labor Regulations in Developing Countries: A Review of the Evidence and Directions for Future Research," Social Protection and Labor: The World Bank, SP Discussion Paper No.0833 October.

Buechtemann, C.F., ed. 1992. Employment Security and Labor Market Behavior: Interdisciplinary Approaches and International Evidence, Ithaca, NY: ILR press, Cornell University.

Clinebell, Sharon K; and John M. Clinebell. 1994. "The Effect of Advance Notice of Plant Closings on Firm Value, Journal of Management; v.20.3 (Fall): 553-565.

Diamond, P. A., and J. A. Mirrlees. 1978. "A Model of Social Insurance with Variable Retirement." Journal of Public Economics 10: 295-336.

Emerson, Michael. 1988. "Regulation or Deregulation of the Labour Market; Policy Regimes for the Recruitment and Dismissal of Employees in the Industrialized Countries," European Economic Review 32 (1988): 775-817. 
Eswaran, Mukesh, and Ashok Kotwal. 1985. "A Theory of Contractual Structure in Agriculture," American Economic Review, v. 75.3 (June): 352-67.

Frederiksson, Peter, and Bertil Holmlund. 2006. "Improving Incentives in Unemployment Insurance: A Review of Recent Research," Journal of Economic Surveys, vol.20.3: 357- 386.

Galdon-Sanchez, Jose E. and Maia Guell. 2003. "Dismissal Conflicts and Unemployment," European Economic Review, v.47.2 (April): 323-35

Gavin, Michael.K. 1986. "Labor Market Rigidities and Unemployment: The Case of Severance Costs," Federal Reserve International Finance Discussion Papers, No, 284. http://www.federalreserve.gov/pubs/ifdp/1986/284/ifdp284.pdf

Gombola, Michael J.; and George P. Tsetsekos. 1992. "The Information Content of Plant Closing Announcements: Evidence from Financial Profiles and the Stock Price Reaction," Financial Management v21.2 (Summer): 31-40.

Hallock, Kevin F. 2009. "Household Risks: Job Loss and the Fraying of the Implicit Employment Contract," Journal of Economic Perspectives, v. 23.4 (Fall): 69-93.

Heckman, James J., and Carmen Pagés. 2004. "Introduction," in Heckman and Pagés, eds., Law and Employment: Lessons from Latin America and the Caribbean, Chicago, The University of Chicago: 1-107.

Holmlund, Bertil. 1998. "Unemployment Insurance in Theory and Practice," Scandinavian Journal of Economics, 100(1): 113-141.

Hopenhayn, Hugo A. and Juan Pablo Nicolini. 1997. "Optimal Unemployment Insurance," Journal of Political Economy, 105.2 (April): 412-438.

Kahn, Charles, and Gur Huberman. 1988. "Two-sided Uncertainty and 'Up-or-Out' Contracts," Journal of Labor Economics v6.4 (October): 423-44.

Karni, Edi, "Optimal Unemployment Insurance: A Survey" 1999. Southern Economic Journal, 66 (October): 442-65.

Kreiner Claus Thustrup, and Torben Tranæs. 2005. "Optimal Workfare with Voluntary and Involuntary Unemployment," Scandinavian Journal of Economics 107(3): 459-474.

Lazear, Edward P. 1990. "Job Security Provisions and Employment," Quarterly Journal of Economics 105 (August), 699-726.

Malcomson, J. 1999. "Individual Employment Contracts," in Orley Ashenfelter and David Card, eds. Handbook of Labor Economics, Vol. IIIB, Chapter 35, North Holland Press pp.2291-2372.

Nickell, Stephen, J. 1978. "Employment and Labour Demand over the Cycle." Economica NS 45.180 (November): 329-345.

OECD. 1999. "Employment Protection and Labour Market Performance," in OECD Employment Outlook, Paris: OECD.

OECD. 2004. "Employment Protection Regulation and Labour Market Performance," in OECD Employment Outlook, Paris: OECD, Chapter .

Parsons, Donald O. 1986. "The Employment Relationship: Job Attachment, Work Effort, and the Nature of Contracts" in Orley Ashenfelter and Richard Layard, eds. Handbook of Labor Economics, Vol. II, North Holland Press: 789-848.

Parsons, Donald O. 1996. "Imperfect "Tagging" in Social Insurance Programs," Journal of Public Economics 62, 1996, 183-207.

Parsons, Donald O. 2011a. "Mandated Severance Pay and Firing Cost Distortions: A Critical Review of the Evidence," In Robert Holzmann and Milan Vodopivec, eds., Improving 
Termination Pay: An International Perspective, Washington, DC: World Bank. (Available as IZA DP. 5776.)

Parsons, Donald O. 2011b. "The Firing Cost Implications of Alternative Severance Pay Designs" In Robert Holzmann and Milan Vodopivec, eds., Improving Termination Pay: An International Perspective, Washington, DC: World Bank. . (Available as IZA DP. 4967.)

Parsons, Donald O. 2011c. "Severance Pay Mandates: Firing Costs, Hiring Costs, and Firm Avoidance Behaviors," mimeo, George Washington University. (Available as IZA DP. 5876.)

Pavoni, Nicola, 2007. "On Optimal Unemployment Compensation." Journal of Monetary Economics v54: 1612-1630.

Prendergast, Canice. 1993. "The Role of Promotion in Inducing Specific Human Capital Acquisition," Quarterly Journal of Economics v 108.2 (May): 523-34.

Prendergast , Canice. 1999. "The Provision of Incentives in Firms," Journal of Economic Literature," v 37: 7-63.

Reid, Joseph D., Jr.; 1977. "The Theory of Share Tenancy Revisited-Again," Journal of Political Economy, v 85.2 (April): 403-07.

Rosen, Sherwin. 1985. "Implicit Contracts: A Survey," Journal of Economic Literature 23 (September): 1144-1175.

Salanié, Bernard. 2005. The Economics of Contracts: A Primer, Second Edition, MIT Press.

Sampson, A.A. 1978. "Optimal Redundancy Compensation," Review of Economic Studies 45.3 (October): 447-452.

Shavell, Steven and Weiss, Laurence. "The Optimal Payment of Unemployment Insurance Benefits over Time." Journal of Political Economy 87 (December 1979): 1347-1362.

Viard, Alan D. 2001. "Optimal Categorical Transfer Payments: The Welfare Economics of Limited Lump-Sum Redistribution," Journal of Public Economic Theory 3 (October): 483-500. 
Table 1

Information Asymmetries and Optimal Layoff Contract Provisions

With Consequences for Consumption across States

\begin{tabular}{|c|c|c|c|c|c|}
\hline & & & & & \\
\hline & GE & $\begin{array}{c}\text { FIRST } \\
\text { BEST } \\
\text { LAYOFF }\end{array}$ & ORC & FCC & $\begin{array}{c}\text { ORC/ } \\
\text { FCC }\end{array}$ \\
\hline & $(1)$ & $(2)$ & $(4)$ & $(3)$ & $(5)$ \\
\hline & & & & & \\
\hline Phi Bounds & & & & & \\
\hline & & & & & \\
\hline$\varphi^{C}$ & NA & 0.475 & 0.515 & 0.505 & 0.535 \\
\hline$\varphi_{2}^{C}$ & NA & NA & & 0.714 & 0.714 \\
\hline $\boldsymbol{\Phi = 0 . 5 5}$ & & & & & \\
\hline & & & & & \\
\hline W1 (WAGE) & 0.925 & 0.908 & 0.908 & 0.925 & 0.925 \\
\hline B (SEV) & NA & 0.208 & 0.347 & 0.11 & 0.234 \\
\hline b (UI) & NA & 0.7 & 0.391 & 0.7 & 0.424 \\
\hline & & & & & \\
\hline & & & & & \\
\hline C1 (EMP) & 0.925 & 0.908 & 0.908 & 0.925 & 0.925 \\
\hline C2 (UNEMP) & 0.925 & 0.908 & 0.738 & 0.81 & 0.659 \\
\hline C3 (REEMP) & 0.925 & 0.908 & 1.047 & 0.81 & 0.934 \\
\hline & & & & & \\
\hline
\end{tabular}

GE = guaranteed employment (no layoff)

LAYOFF

FIRST BEST $=$ full information

ORC = offer revelation constraint

$\mathrm{FCC}=$ firing cost constraint

ORC\&FCC =both offer revelation and firing cost constraints may be effective. MODEL:

$$
\begin{array}{ll}
U=\ln (C) & \text { if employed; } \\
U=\ln (C)+\ell, \quad \ell>0 & \text { if unemployed. }
\end{array}
$$

PARAMETERS

$$
\begin{aligned}
& \ell=0.35 \\
& \rho=0.85 \\
& v=1.0 \\
& \theta=0.5 \\
& \sigma=0.7\left(W^{R}=\sigma v=0.7\right) \\
& \varphi=0.55
\end{aligned}
$$

$\varphi^{C}$ GE/FB, GE/ORC, GE/FCC, and GE/FCC\&ORC boundaries.

$\varphi_{2}^{C} \quad$ FCC\&ORC/ORC boundaries. 
FIGURE 1

CONTRACT PROVISIONS AND CONSUMPTION ACROSS OUTCOMES BY REEMPLOYMENT PROBABILITY $\varphi$ FIRST BEST CONTRACT

Panel A: Consumption

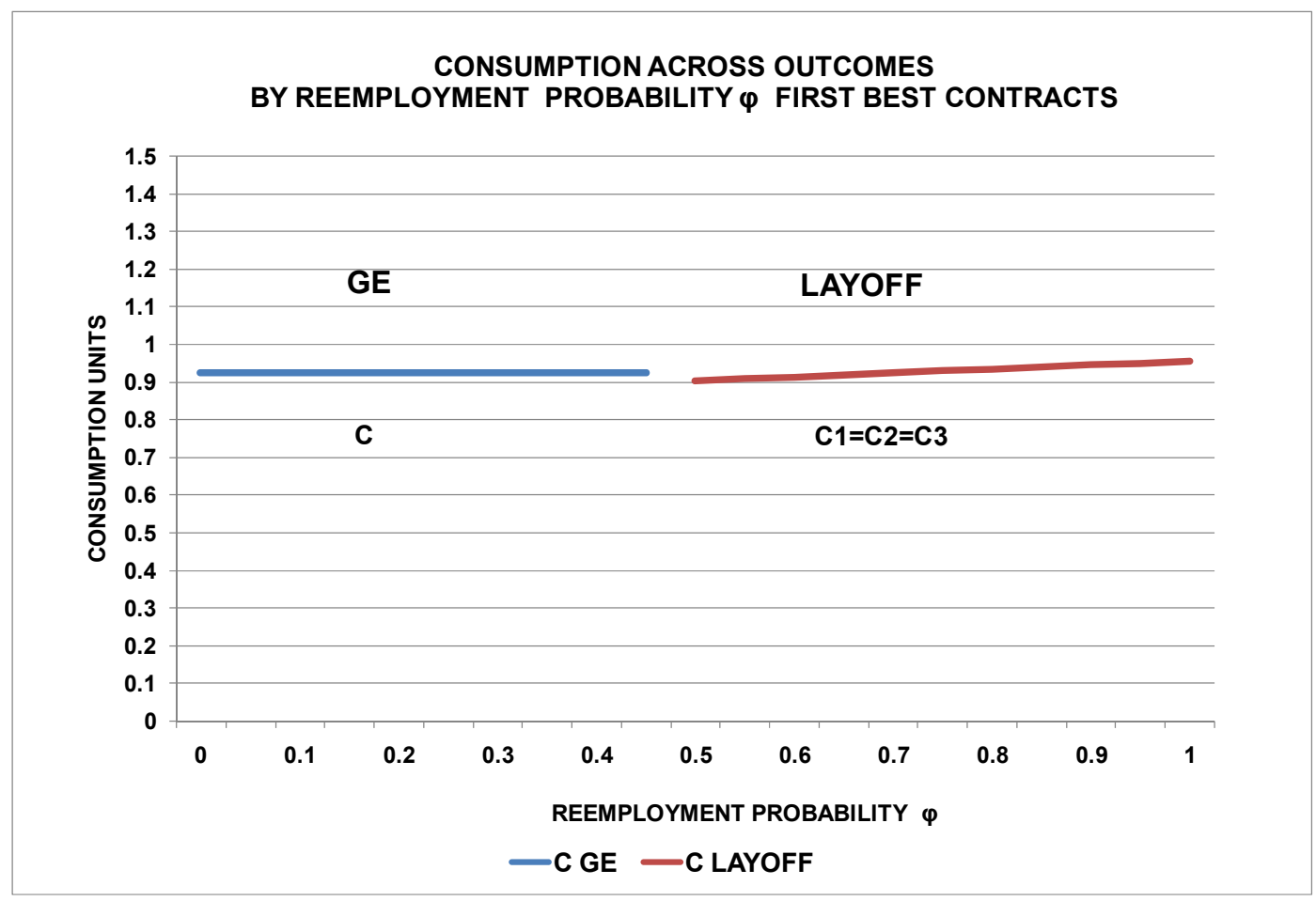

Panel B: Contract Provisions
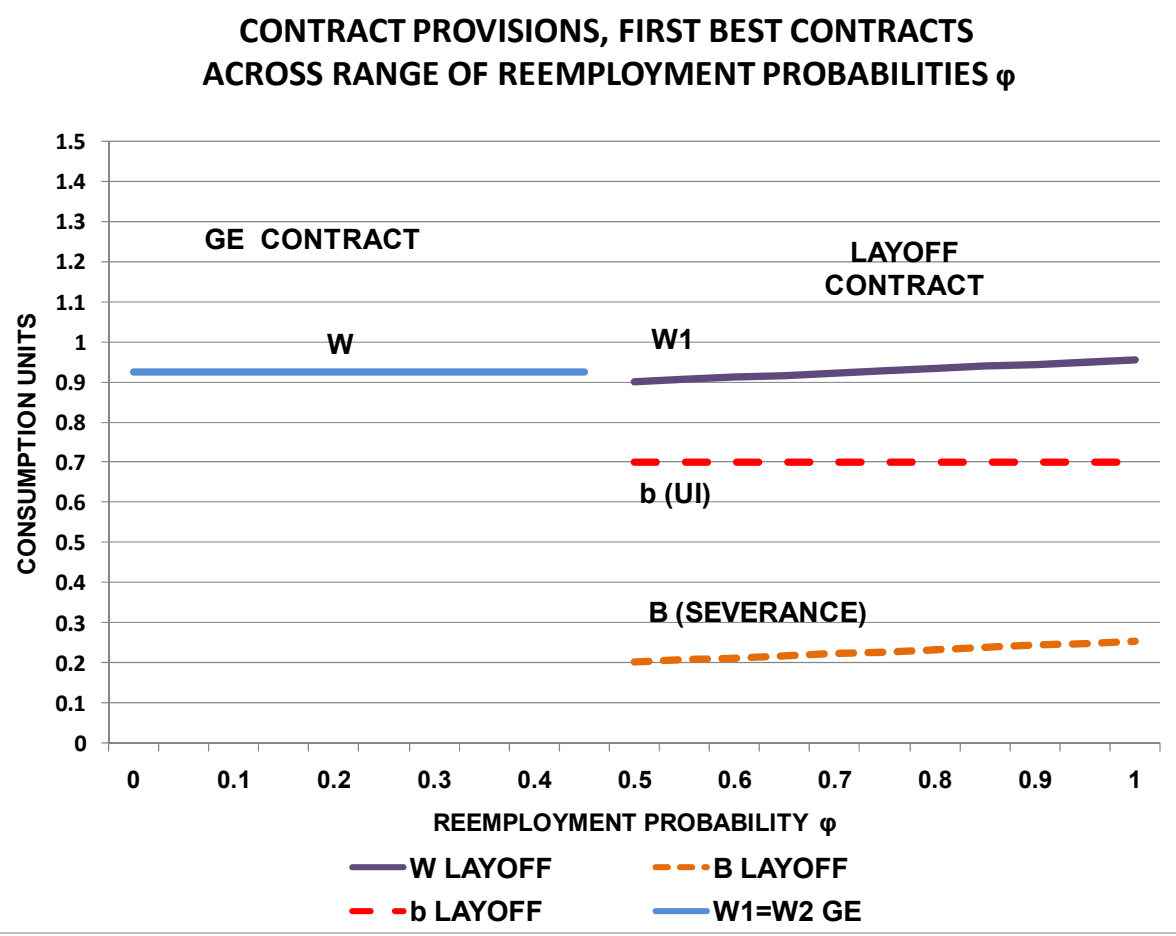
FIGURE 2

CONSUMPTION AND CONTRACT PROVISIONS ACROSS OUTCOMES BY REEMPLOYMENT PROBABILITY $\varphi$, UNDER FIRING COST CONSTRAINT (ORC)

Panel A: Consumption

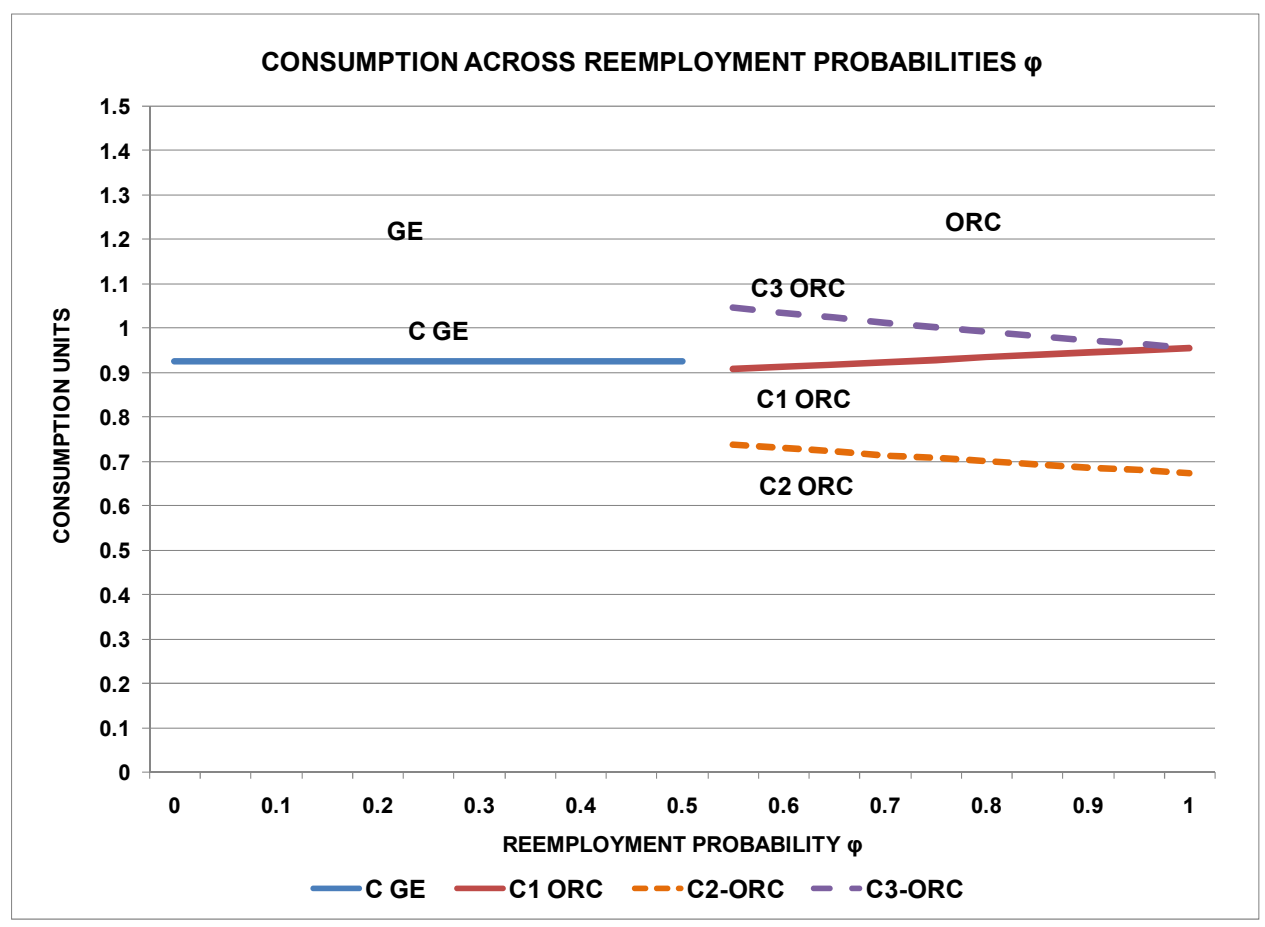

Panel B: Contract Provisions

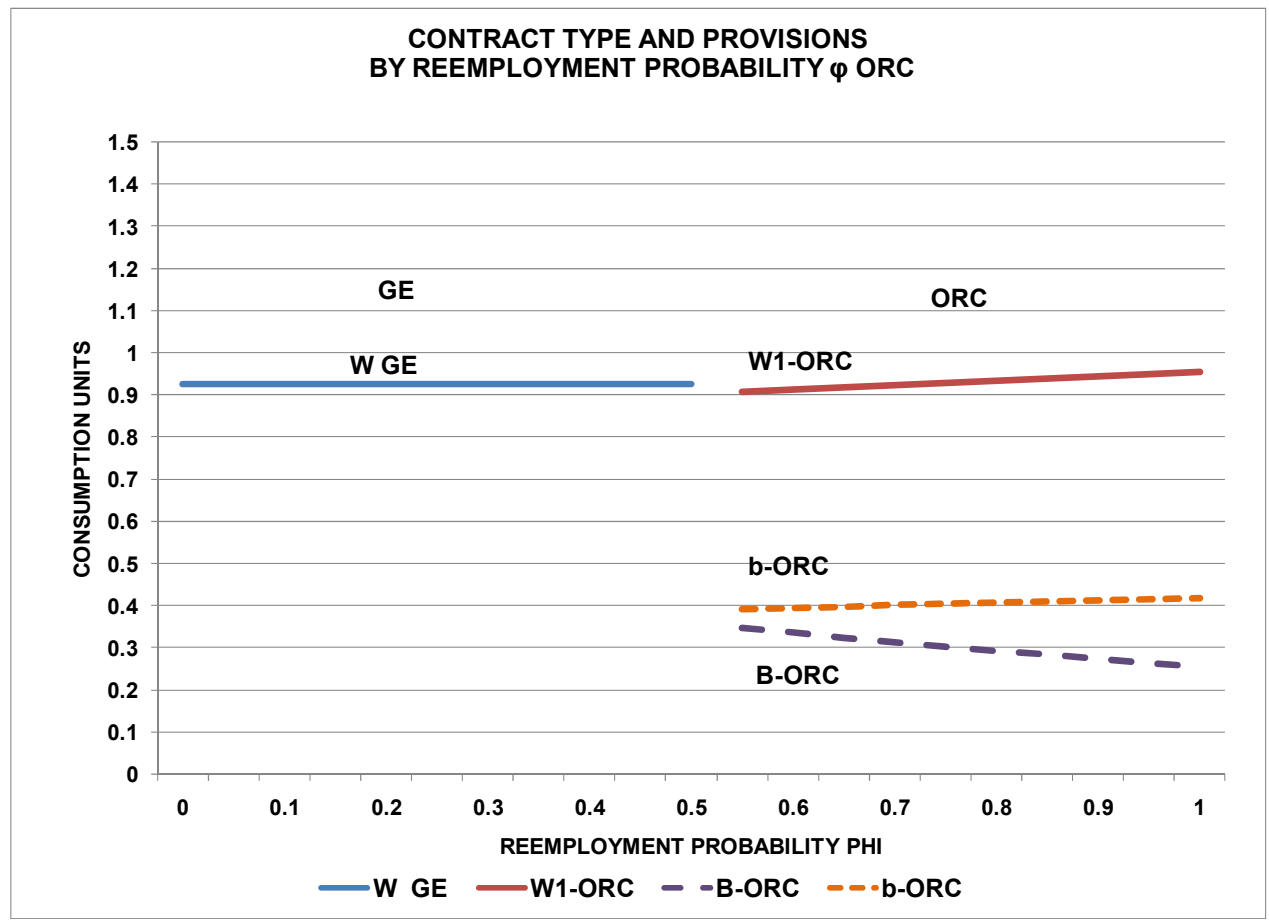


FIGURE 3

CONTRACT PROVISIONS AND CONSUMPTION ACROSS OUTCOMES

BY REEMPLOYMENT PROBABILITY $\varphi$ FCC

Panel A: Consumption

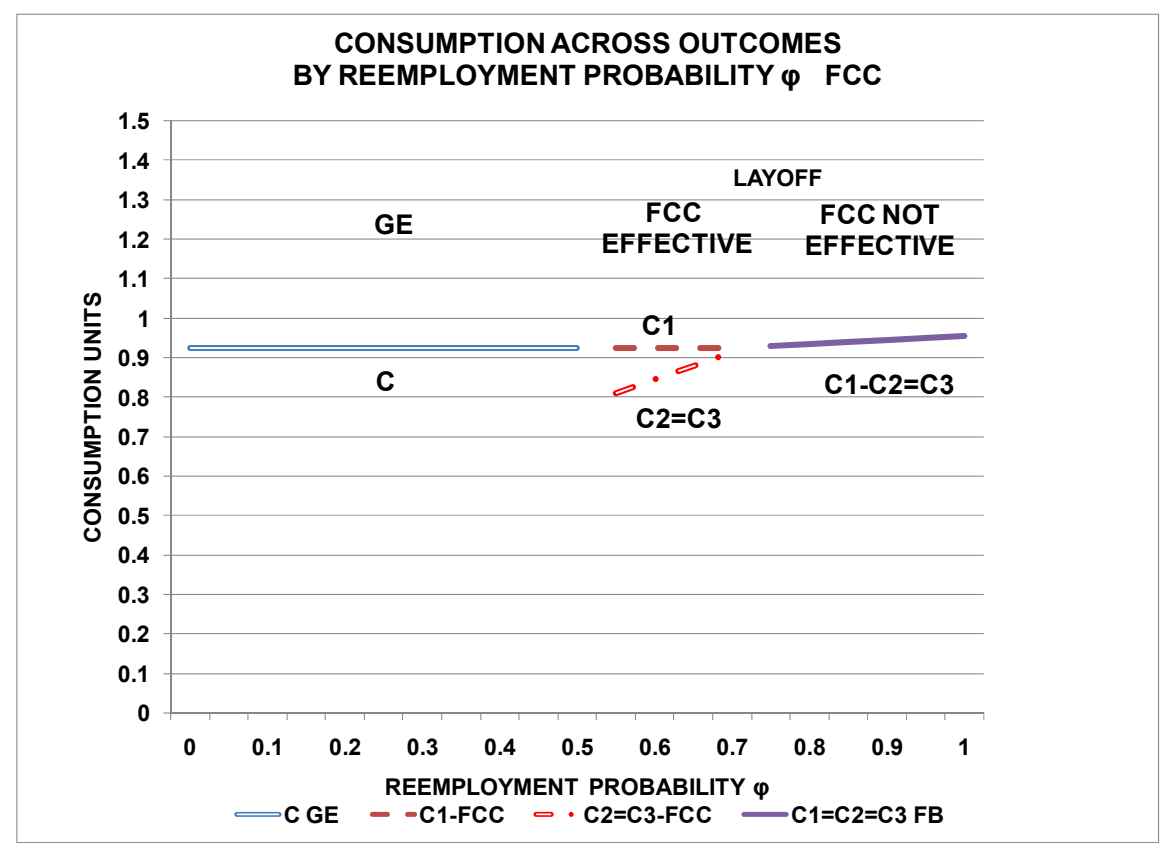

Panel B: Contract Provisions

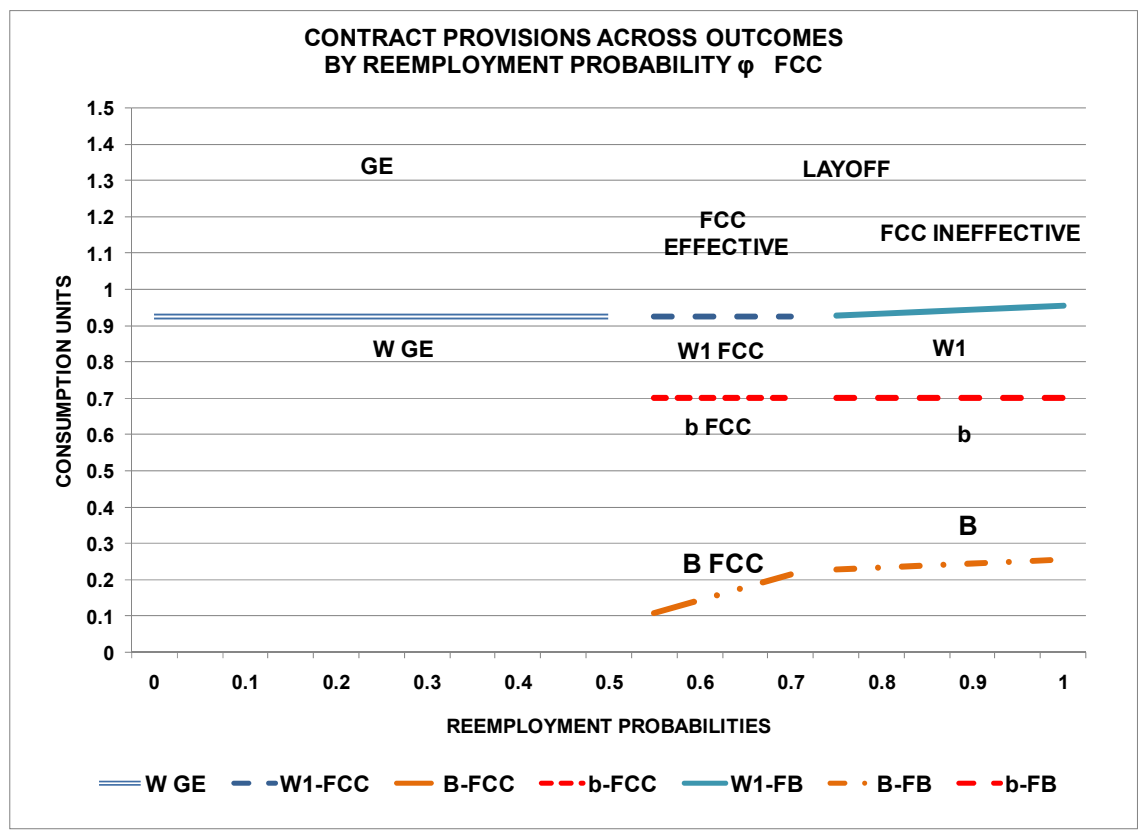


FIGURE 4

CONTRACT PROVISIONS AND CONSUMPTION ACROSS OUTCOMES

COMBINED ORC\&FCC BY REEMPLOYMENT PROBABILITIES

\section{Panel A: Consumption}

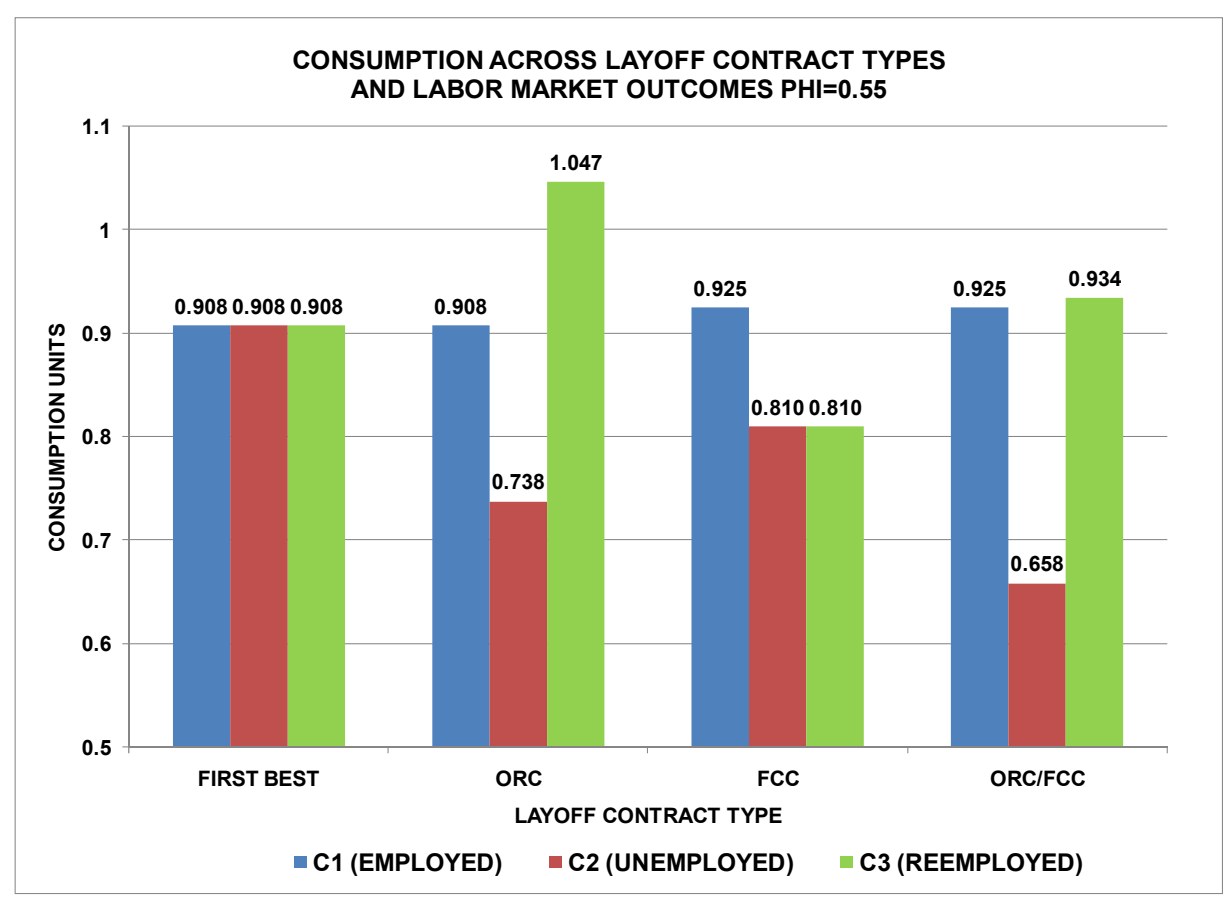

Panel B: Contract Provisions

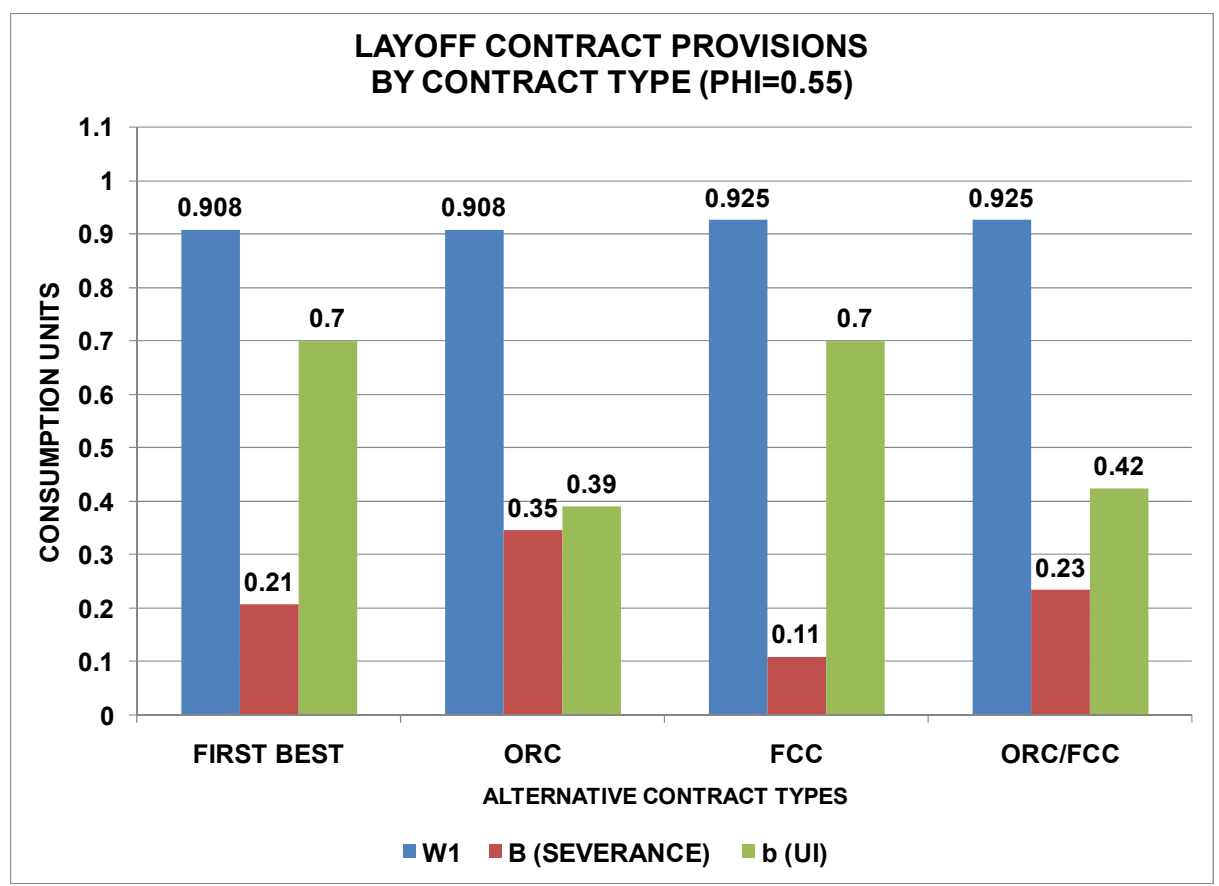


FIGURE 5

CONTRACT PROVISIONS AND CONSUMPTION ACROSS OUTCOMES COMBINED ORC\&FCC BY REEMPLOYMENT PROBABILITIES

Panel A Consumption

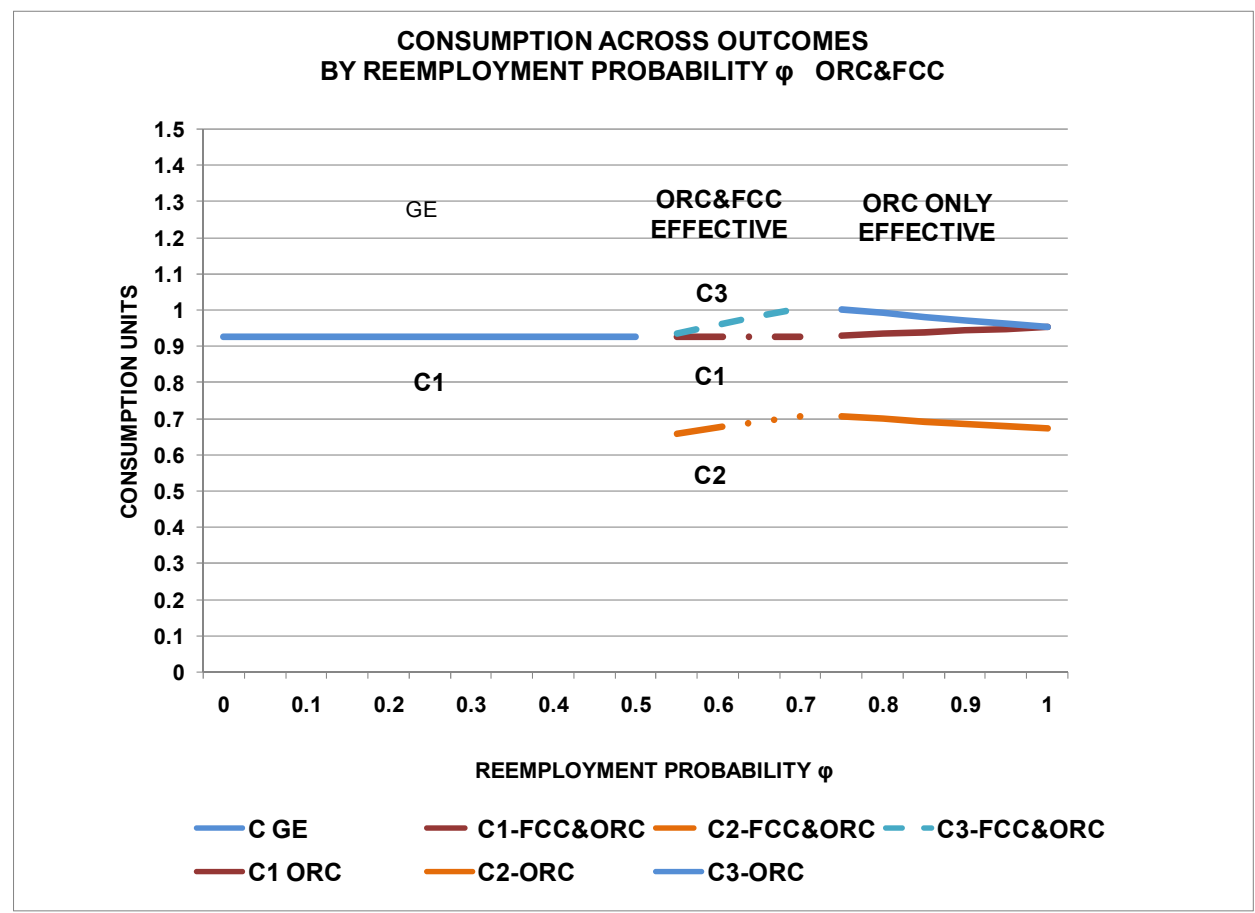

Panel B Contract Provisions

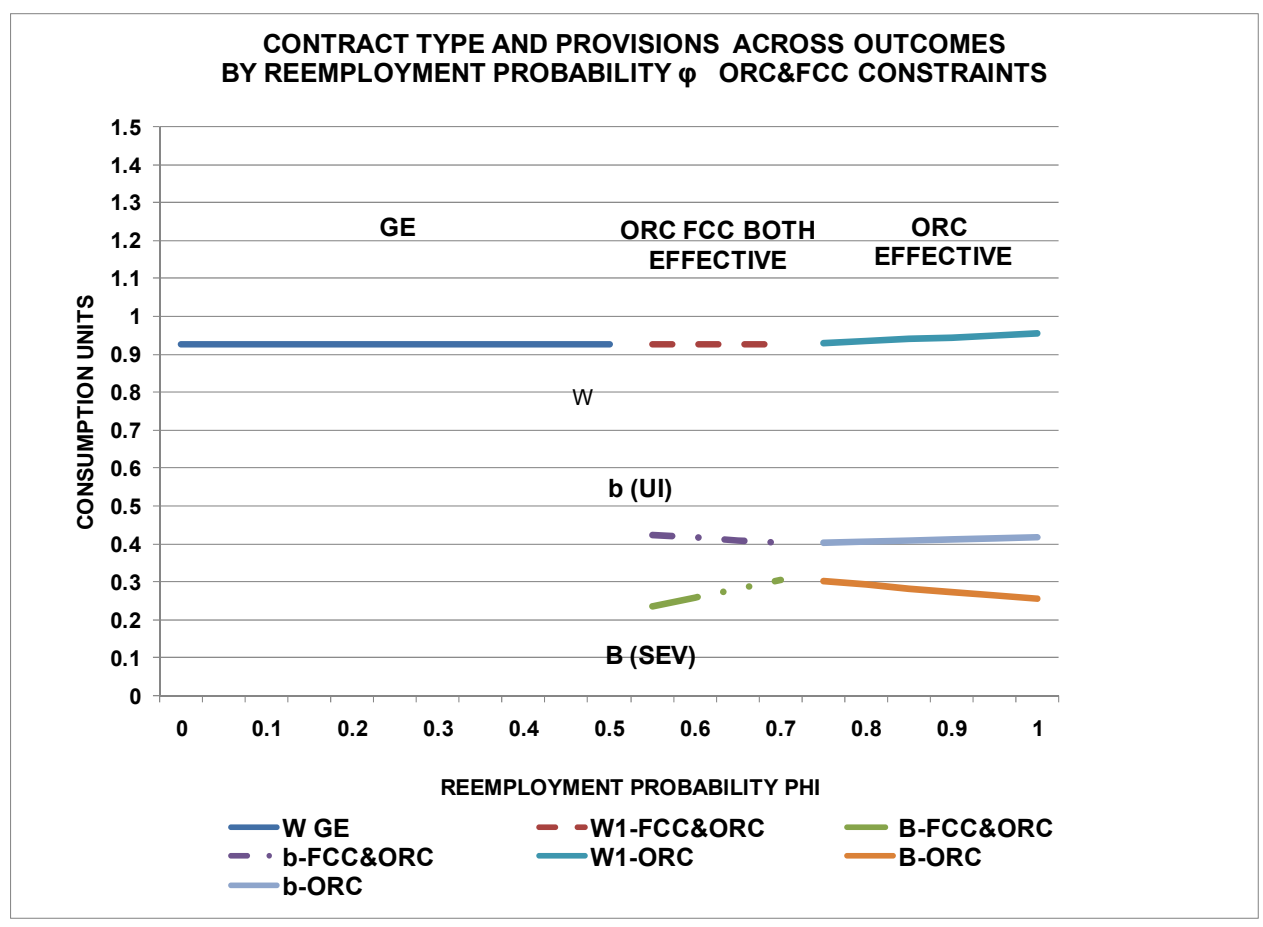

